Original Research Paper

\title{
Climatic Hazards and Social Crisis: A Quick Mitigation Approach to Accelerate Sustainable Development
}

\author{
${ }^{1}$ M.A. Rakib, ${ }^{2}$ M.S. Akter and ${ }^{3}$ Kushal Majumder \\ ${ }^{I}$ Department of Disaster Management, Begum Rokeya University, Rangpur, Bangladesh \\ ${ }^{2}$ Department of Statistics, Jahangirnagar University, Savar, Dhaka, Bangladesh \\ ${ }^{3}$ Department of Environmental Sciences, Jahangirnagar University, Savar, Dhaka, Bangaldesh
}

Article history

Received: 03-04-2015

Revised: 20-01-2016

Accepted: 30-01-2016

Corresponding Author:

M.A. Rakib

Department of Disaster

Management, Begum Rokeya

University, Rangpur, Bangladesh

Email:

rakibmamun_ju@yahoo.com

abdur.rakib84@yahoo.com

\begin{abstract}
Climate change and its negative consequences frequently impede to social development through mal-structural function of socioeconomic status but prospective mitigation approach may accelerate to social sustainability. This paper investigates to existing climatic hazards along with functional damage in a society that, how climatic hazards make vulnerable to the social people and evolve a new mitigation pathway to rescue from food insecurities in the community. Depending on observational status, it has been drawn an overall thematic citation and outline regarding with the respondents perception. In the study area, maximum number of people were found to be highly affected owing to long term climatic shocks which is appeared as a social disaster in the aspects of poor socioeconomic status and livelihood crisis. To get sustainability, it is very important to reduce the degree of climatic risk through evolving new technique or technological advancement as to operational feature. As an operational tools, sustainable social clustering technique would be very much effective to search out the more climatic vulnerable people from the communities. Its suggestive policy could be helpful to take the initiatives for the special caring regarding with the need basis insecure people. In addition, better understanding and outstanding results would be effective to cope with climatic shocks and social crisis.
\end{abstract}

Keywords: Climatic Hazards, Social Crisis, Local Perception, Mitigation Approach, Sustainable Social Clustering Technique, Probable Policy and Chilmari Upazilla, Bangladesh

\section{Introduction}

Natural and anthropogenic hazard directly or indirectly inhibit to daily life style through property damaging and functional development impairment. It may have several impacts in case of short-term and longterm consequences in the local and global scale. Human security implies to sound life style with the fulfillment of fundamental rights. Whereas it could be ensure sustainable development in the community. Several latent hit act as open-secret impairing parameter in the social development trends. As a critical parameter for the social development it must be kept remain in the tolerance level which it would be helpful to maintain any worsen environmental condition. Meanwhile, developed country tried to assured to take vulnerable parameter as a crucial fact at the time of environmental crisis. On the other hand, developing country not so good enough prepared to face any kind of environmental hazards owing to financial and technological crisis.

Climate change and its impact influence to the interaction of other dynamics across temporal and biophysical dimension and from local to global levels, political and temporal (Ericksen et al., 2009). Environmental parameter and climatic variables changing trends evolve instance threat to human being and living organisms through occurring atmospheric turbulence. A number of hazards frequently occurred in several times in a year like as flood, drought, tornado and cyclone due to climatic stress and/or imbalance condition. It may varies from place to place and existing geographical position. In addition, pollution source and polluting parameter can influence to its frequency and magnitude. The technological advancement can helps to 
measure natural hazards (e.g., intensity, magnitude and frequency) and its probable functional damage. In the south Asian countries, Bangladesh is one of the most vulnerable country where natural and anthropogenic hazards are frequently occurred and sometimes appeared as a devastating disaster. Consequently, from 1973 to 2011, almost twenty drought events recurrently occurred in Bangladesh (Habiba et al., 2011). The climatic variables such as temperature, rainfall, evapotranspiration and humidity along with the seasonal feature significantly influence to agricultural activities. Its discontinuation or irregular pattern could be influence to natural environmental components. The rainfall uncertainty is one of the utmost cause of drought in the north-western part of Bangladesh (Habiba et al., 2012). Temperature act as controlling parameter to control the whole climatic variables. Paul (1998) reported that, lower rate of rainfall occur in the yearlong rather than others country. Simultaneously, gradually increasing temperature and decreasing rainfall that is primary cause of drought hit owing to climatic stress (West et al., 2007). Now north-western part of Bangladesh identified as regular and irresistible drought prone area (Paul, 1998). The continuous drought events and it impacts adversely affect to the social vulnerability and food security (Rakib et al., 2014). On the other hand, Onethird places in Bangladesh has been identified as more vulnerable to flooding hazards but it may differ from spatially or temporally basis (Paul, 1997). Climate change act as a driving force to affect the hydrological cycle. In terms of considering some issues like monsoon rainfall, glacier and sea level rise, Ganges-Brahmaputra river basin identified as a more vulnerable point in the world (Gain et al., 2011). The average water discharge of the Brahmaputra River was recorded around 20,000 $\mathrm{m}^{3} \mathrm{~s}^{-1}$ (Immerzeel, 2008). In addition, flooding hazard and its devastating activities directly hit to the human settlement, agricultural activities, farmland, street (e.g., metallic or non-metallic), town or city and etc. It might be disappeared in the long term way of several actions like as river shifting, heavy rainfall and rush water downward movement at a time. Long term climatic stress and its variation may lead to unstable and/or non-steady rainfall and temperature. In the consequences of rainfall uncertainty, river discharge pattern has been changed to before stage of the river flow and it may lead to damage regulation of river depth through filling up huge amount of sands with other debris materials. In the long term action of flooding hazard, a thousand of peoples become shelterless through loosing not only properties but also every aspects of life. In terms of social security, it is the supreme threat and appeared as a deadly event on the way to social development. Flooding hazards and social vulnerability negatively impacted to the communities' livelihood and socio-economic condition. It could be a better way to unshackle from natural curse and long term impacts through sustainable development research along with the guideline to reduce environmental risk.

Flooding hazards may be the fact of concerning issues for the developing countries like Bangladesh. But in the realistic point of view that, sustainable research can be ensure to better understanding on the factual issues related to environmental crisis. In this study, it is tried to deal with several aspects of the climatic hazards (e.g., drought and flood) along with the social concepts and local adaptive measures. Along with these, it also dealt with new mitigation approach to climatic stress and social crisis depending on conceptualization and thematic views. A number of question has been raised owing to long term climatic hazards and negative consequences in the society, how climatic hazards affect to the socioeconomic growth and development? How and when climatic hazards appeared as a social disaster? How social disaster influence to make food insecurity? How climatic hazards mitigation approach will be effective to reduce social crisis through applying cluster technique? However, these questions answer would be helpful to find out a new outline to rescue climatic insecure people from the society and probable recommended policy could be guide to new way for the sustainable development.

\section{Research Methods}

This study was conducted at the Chilmari Upazilla (Small administrative unit (e.g., police station) which consist of several union) in the Kurigram district where most of peoples are victimized due to unexpected climatic events. Long term instability of climatic variables is forced to change the overall climatic condition. Drought and flood several times hit to the local people along with the loss of their life and properties. Most of the people were identified who were suffered from food shortage problem at the several times in a year. Many researches has been performed on drought and flooding issues but a number of problem appeared owing to environmental hazards which associated with health risk and unexpected property loss. However, the sampling technique and observational data collection procedure were followed at the significance level of confidence interval. It was performed using qualitative technique which was statistically sound.

The study was conducted along with well plan and design. It was consisted with several experimental technique and procedure to follow qualitative research approach. Depending on individual circumstances regarding with judgment, including both open and closed questions asks as a formal interview (Patwary et al., 2012). The qualitative research may help to build up 
conceptual data series and realistic point of the problematic area through knowledge shearing approach. Knowledge shearing approach get emphasis on long term experience and its justification with the objectives of the thematic study. A total number of three data collection methods allowed for triangulation system, which examined, corroborated, improved the credibility and trustworthiness or rationality of the data (Gershberg, 1998; Gibson, 2004). In this study, three types of experimental strategy were employed like as questionnaire survey, focus group discussion and informal dialogue. Questionnaire survey is most important approach for the qualitative research. It was suggested that prescribe formulated form along with specific information on subjective matter and goal. In addition, Sample was collected using randomly questionnaire survey technique that's why, two types of respondents observed thereby one is literate (e.g., able to read and write) and another illiterate (e.g., not able to write signatory name). Male and female were considered to be a significant informant on long term climatic hazards in terms of age and the realization ability perspective to natural environment and its changing pattern. Sometimes, visual expression is a reflection of relevant discussion and just it more clear and congruent (Rakib et al., 2015). Respondent's age range were found to be $20-70$ years old. It was formulated starting age from 20 years owing to get more significant information along with pragmatic views on environmental impacts.

The interview was taken from local respondents on climatic effects like drought. The questionnaire was randomly (Rakib et al., 2014) distributed among the local respondents to get the lucid concept about the long term environmental stress. Questionnaire was framed with four parts like Part-1 was contained "demographic information" which dealt with personal information like as "Age", "Occupation", "Family member", "Earning Person", "Sex", "Educational status" and "Marital status", Part-2 contained thematic concept of the local respondents on "drought and flooding impacts" and it was also consisted with several questions like as "Knowledge on climatic concept", "Thematic views on climatic hazards", "Perceptional attitude on drought", "Perceptional attitude on flood", "Observational status on existing Hazards" and "Personal justification on long term impacts". However, conceptual information act as genuine factor for the problem justification. Meanwhile, environmental impacts and its negative consequences reflects to its surrounding components as a ocular witness like as long lived tree and aged people, Part-3 contained "local environmental hazards" which is badly impacted on local inhabitants and it was also oriented with some structural questions like as "Regional and national level concept on environmental hazards", "Core views on long term impacts", "Core views on term environmental changes", "Core views on social insecurities", "More details about livelihood pattern", "More details on productive trends", Observational facts on family crisis" and "Thematic, realistic and emotional citation" and Part-4 contained local concept to "adaptive strategy" at the time of local hazards which was formulated by some thematic questions such as "Justification of the lifesaving strategy against with environmental Hazards", "Mainstream challenging site', "Mainstream challenging strategy on hazards", "Evolving technique for the adaptation approach", "Situational case on time measure" and "Protective measures in favor of government, nongovernment (national and international) organization”. The Focus Group Discussion (FGD) was performed among the local participants. It was divided into three subgroups (e.g., group one contained 23 peoples, group two contained 27 peoples and group three contained 28 peoples) for getting more detail information. Participant's views were more informative which was coincided with the previous scientific evidence. FGD question was similar among the three groups which were employed at the same approach and target. The Rapid Rural Appraisal (RRA) is an outstanding approach for the qualitative research and it was applied for the focus group discussion for getting the clear concept about vulnerability and socioeconomic status (Chambers, 1994). Most of the question were conducted on histological chronology on the basis of aged people from late to early stage. Whereas, it was approached overall concept on "Environmental risk, hazards and disaster" "Observational problematic site" "Situation and social factor" "Environmental condition" "Knowledge on climate change" "Changing trends on time" "Observable local impacts" "Changing pattern of landscape" "Agricultural Impacts on production rate" and "Ultimate results for just now from your life time". It was more informative and well designed to perform a structural research on environmental hazards through qualitative approach. On the other hand, the informal dialogue was also performed to ensure the better understanding on the climatic effects and long term consequences at the local scale. It was taken from the floating people like as street people, pedestrian, local gathering at the tea stall and local convenient shop. This strategy helps to get more accurate information from the local respondents without any preparation or action. It was performed as non-structural pattern but followed by random sequence. In contrast, conversation tracking system "pointed out" instantly to be made sequential record to find out thematic views and real concept (Rakib et al., 2015). The data coding system were performed to make the easiest way to calculate the collected data in purpose of accumulation, arrangement 
and analysis (Corbin and Strauss, 1990). Depending on the situational case observation, it was tried to find out the main problematic site at the climatic hazard area. As a guideline, evolved new approach (e.g., specific outline on this thematic research) might be helpful to mitigate on time climatic hazards measures and fix to adaptive capacity build up among the communities.

\section{Results and Discussion}

Natural environment and its components are gradually affected by the human intervention. It is very important to notice negative consequences on climatic variables which results from the long term impacts of settlement and productive sector. Peoples directly or indirectly depends on environmental outcome while it may coincide with livelihood patterns. At this time, challenging climatic shocks hits to local communities in case of growing poverty through facing continuous environmental latent impacts. The IPCC reported that no sufficient study perform on the distribution of poverty at the household level regarding with poverty traps and critical household in the aspects of climatic and nonclimatic stressors (IPCC, 2014). Sometimes it is appeared as aggressive mode to engulf fundamental rights of the local communities. Local people of the study area was observed too much congenial and more helpful to experience based information shearing on environmental crisis and livelihood pattern. Long term consequences of flooding hazards may lead to change lifestyle, food chain sustainability and normal livelihood pattern (Rakib et al., 2015). In the aspects of local views, almost $89 \%$ people were conscious in terms of local name "bonna and khora" (Flood and Drought). In this regarding issues, 34, 41, 67 and 95\% respondents were found to be conscious on climatic knowledge, climatic hazards, drought and flooding events respectively. However, observational perception rely on the factual events related to life span and accompanied with some special events which may draw an outline in one's soul and mind. Sometimes, scientific evidence reflect to one's perceptional views on climatic condition and existing environmental crisis related to socioeconomic condition. As driving parameter of a society, socio-economic condition might be played as a key parameter to ensure sustainability. In addition, social security and its responsible parameter leads to build up resilience livelihood. A number of authors (Adger, 1999; Turner et al., 2003; Luers et al., 2003; Tompkins and Adger, 2004) reported that, ecological system and social resilience is increasing which could be achieved through standard action in the aspects of two factors, one is for accelerating wellbeing and resource utilization access and insurance and another is for enabling the adjustment of specific population to recover from loss.

\section{Environmental Risk and Social Development}

Environmental risk may associate with several types' of risk which is negatively impacted on social development. It is responsible to confined social development factor in a one point and make up the barrier to meet up fundamental rights. Social welfare, development and sustainability may ensure to encourage among the communities to do human welfare activities. In the present study, almost $78 \%$ people were found to be not socioeconomically sound. Chronological climatic hazard and river bank erosion made them to out bursting, helpless, shelterless and landless. In addition, pragmatic experience and long term thematic views may help to lead future life style with making perceptional future plan. Nevertheless, climate change may be a responsible factor to make them poor to poorer and the vulnerability of the communities.

\section{Knowledge on Climatic Concept}

The climate concept depends upon vulnerability and adaptation. Vulnerabilty is defined as a extent of climate change which may damage the system of a society. The vulnerability of a region depends to a great extent on its wealth and that poverty limits adaptive capabilities. On the other hand adaptation is defined as a process by which people reduce the adverse effect of climate upon their health, wealth and well-being. They took all sorts of hazards as common phenomena and they are used to such kind of calamities. This hazards manipulates their mental peace to fear. In the aspects of the study, $41 \%$ peoples were not informed about the prospective climatic impacts and long term future threats. Its might be insist to ignorance and lack of educational qualifications among the communities. Education is a key factor to evaluate and helps to build up adaptive strategy against with disaster and increase to one's resilience to disasters and quality of life (Tong et al., 2012). Education can also help to understand flood forecasting, early warning and one's can reduce loss using their previous experience (Smith and Petley, 2009).

\section{Thematic Views on Climatic Hazards}

The thematic framework of climatic hazard mainly segmentized by vulnerability, risk and adaptation. Moreover, some steps are- the accessment of vulnerability for climatic adaptation, adaptation strategies for vulnerability mitigation, impact assessment to adaptation priorities and thematic risk assessment exercises in different affected areas. Survival from every crisis coming from every spheres of society is the only determination of those victims. Regarding with the respondents, general peoples were not so conscious instance climatic hazards and its protective measures. 
According to their citation, it is completely unusual and unpredicted occurrence, not on time events.

\section{Perceptional Attitude on Drought}

Drought is defined as a hazard which happens by not only lack of precipitation and high temperatures but also by overuse and overpopulation. Most people think of a drought as a period of unusually dry weather that persists long enough to cause problems such as crop damage and water supply shortages in crop field. Drought not only has agricultural effect but also has hydrological, meteorological and socioeconomical effect upon a society. Around $45 \%$ respondents of the study area reported that, negative impacts of drought events affect to the daily life style and basic needs of the communities. Its prospective measure are not sufficient to hold normal life style and fulfill the basic needs.

\section{Perceptional Attitude on Flood}

Useually flood is defined as overflow of water that submerges land which is usually dry. Most people think of when they hear the word "flood." Filled to capacity because of heavy rain or melting snow, the water within a river overflows its banks and spreads across the land around it. For them, flood is not only the life-taking event, but also an event which submerges their land and economy as well. Most of the people (41\%) reported that, primary knowledge does not support to our aims and target "how climatic effects negatively impacted on flooding hazards?". Some of the aged people's perception were found to be similar with the scientific of the climatic impacts and its negative impacts in the community.

\section{Observational Status on Existing Hazards}

Every year several kinds of naural hazards visit Bangladesh such as flood, drought, cyclone, tornado, riverbank erosion and landslide. The geographical setting of Bangladesh makes the country vulnerable to natural hazards. Since Bangladesh is a disaster prone country, it is subject to colossal damages to life and property almost every year. The peoples of these area is habituated with this sort of damages and natural hazards as well.

\section{Personal Justification on Long Term Impacts}

The adverse effects are huge in number of this hazards. The loss of agricultural production, damage and destruction of immobile infrastucture, loss of biodiversity and livelihood system, disruption of communication and essential services, loss of human lives and national economy as well are included with this. Door to door awarness building campaign, funds for settlement and rehabitilization, proper pre-disaster peparedness programs should be enhance for the mitigation of these long term impacts.

\section{Poverty and Climatic Hazards}

Several nutritional deficiencies and functional disorder might be evolving due to prolong food shortage. It is more frequently occurred and may vary from place to place, time to time and source of food. But it is now find to be a threat in the specific area which is associated with climatic hazards. The observational case finding on environmental crisis not only regional basis but also large scale implies to worsen climatic condition which negatively impacted on agricultural production sector and absence of nutrition enrich food. In the developing country, food access and utilization, food production and storage has been significantly changed due to unwanted climate change and its changing pattern (Wheeler and Von Braun, 2013). It is directly attributed to malfunction and immaturity of the body organ whereas it may associate with health risk along with cognitive disorder.

\section{Social Crisis and Sustainable Development}

Social development may redirect to its own entity and responsible parameter for getting sustainability in the holistic approach. A number of social parameter is to be a strong parameter to achieve community's sustainability through meting up social crisis. Most of the social crisis evolve from individual factors affecting site which may depends on climatic or environmental crisis in the regional or large scale. It is important to ensure regional basis development through awareness development and met up social crisis. On the other hand, sound environmental condition expedite to development trend with the decreasing social insecurity.

\section{Regional and National Level Concept on Environmental Hazards}

These environmental concept varies from region to region. The adverse effects of a natural disaster or a combination of more than one natural disaster can cause of loss of human lives, livelihood and certainly damage to physical properties. This requires large resources for disaster management including mitigation, recovery and preparedness. Therefore, the impact of these hazards and the resulting environmental degradation turn into a dangerous threat to the socioeconomic development of the country. The situation force to demand for an effective disaster warning and dissemination system. A timely and accurate alert system about impending disasters will help to reduce the loss of human life and property. Its timely measure and protective action might be enhance to social development.

\section{Core Views on Long Term Impacts}

After those long term impacts, the assessment of vulnerability and adaption strategy should be 
prepared. The fullfiment of social demand can be possible to minimization of economic and livelihood loss, the settlement and rehabitilization caused by hazard, the mitigation process and adaptation strategy also. Some sorts of motivational approaches can be ease to the sharp impacts of hazards. On the other hand, natural and manmade threats is a reflection of long term mind setup and expressional emotion. From Table 1, It would be a realistic views of the core realization whereas in the aspects of study it has been appeared a drastic mode of concern.

\section{Core Views on Long Term Environmental Changes}

After occurring a natural hazard, there are many changes took place in the environment. The loss of biodiversity is a big issue. The components of it face a brutal circumstance for their survival. The ecosystem not only hampers but also damaged because of these situation. So, the organisms of that ecosystem may be extinct. The environment they lived past became very much harsh to them as the imbalance of it affects the functional growth of society's living organisms. In the aspects of the study area, it was clear that respondent's perception and observational feature indicated to the problematic site which was gone to be worsen condition. Nevertheless, it might be drawn some irregularities and unavoidable things as an evidence in the communities.

\section{Core Views on Long Term Social Insecurities}

The society faces some sort of insecuties after those hazards took place. The food insecuty is the main fact laid behind this. There is also settlement insecurity and rehabitlzation fact standing beside of this. It's very important to frameout those affected people so that they can get proper releif from those government initiatives, programs and also those social insecurities. The disasters are not only miserable and life taking but also its negative effects may blur society's socio-economic trend. Regarding with the respondents information (Table 1), social insecurities is a part of their life it could be arisen from environmental threats or socioeconomic status. Its major aspects related to unexpectedly changing pattern of the climatic variables and its negative consequences make imbalance to agricultural production rate due to the interference of natural trends of temperature, rainfall and humidity.

\section{More Details about Livelihood Pattern}

Most of the people of our country lives below the poverty margin. They live upon their day to day earning. As a hazard took place, it's very miserable for them to survive as most of the people are farmers. They can not bear the loss of their agricultural production as well as the loss of their residence. So, these hazards has an negative effect upon livelihood pattern. However, it is clear that, livlihood pattern of the study area is completely agriculture dependent. When agricultural production follow downward trends then it might be indicate to worsen socioeconomic condition. According to respodents perception (Table 1), these time more critical to survive against with the fighting of climatic impacts.

\section{More Details on Productive Trends}

There is some big changes commit upon the productive trends after the visit of an hazard. The agricultural aspect is mainly victim of it as the sediments washed away and the nutrients of soil are being contaminated. The soil profile disturbed by flood, landslide, drought or other calamities. The loss of trees and living micro organisms which is the mainstream components of ecosystem, can create an imbalance condition of it. So, the partial change of productive trend is consider to a harsh mark upon the adaption of the society after the hazard visit. Local concept on the agricultural production rate has been coincided with the following trends of the climate change (Table 1). Its negative impact has been changed to the people life style and income generation source through livelihood pathway shifting.

\section{Observational Facts on Family Crisis}

Crisis appears on every family of a society after a disaster visit. Also the economical neglegence appears as they lose all sort of their wealth by those hazard. They live on hardship on that situation and because of the change of their settlement area, they lost their regular jobs and works on agricultural fields as they are being damaged. They feel fear about their near future as it has been came along after the hazard took place (Table 1). General people of the study area were not congenial with their living standard and purposive motivation. They were faced to a number of newly emerging environmental crisis which is directly imposed to social hazards.

\section{Thematic, Realistic and Emotional Citation}

The damage of a natural hazard is so disasterous that a poor family can not adopt this. They face all sort of crisis such as economical, social and so on. They cannot earn on that time, felt many insecurities like as food, shelter and etc. The impacts put bitter experience in society as the communication and essential services disrupted. The nature also victim of it as it face many ecological imbalance. But the affected one's concentration neither upon property loss, nor upon the loss of human lives, they always tries to assign themselves upon something productive which could take them away to the daily lifestyle they lived past (Table 1). Consecutively, real situation of the climatic imbalance disappeared to their (e.g., local people) emotional argument and demand. Thematic views of the local economic condition is not stands for facing future crisis. 
Table 1. Characteristics of the factor affecting regulatory aspects regarding with respondents pragmatic experience (based only aged people) depending on time length from before ( 65 years before) to present

Factors affecting

\begin{tabular}{|c|c|c|c|c|c|}
\hline regulatory aspects & 65 y ago (stage one) & 52 y ago (stage two) & 39 y ago (stage three) & 26 y ago (stage four) & Recent (stage five) \\
\hline $\begin{array}{l}\text { Views on long } \\
\text { term impact }\end{array}$ & $\begin{array}{l}\text { Reflection of the } \\
\text { normal condition }\end{array}$ & $\begin{array}{l}\text { Same as to pervious } \\
\text { status }\end{array}$ & $\begin{array}{l}\text { More or less fluctuation } \\
\text { appeared among the } \\
\text { climatic variables }\end{array}$ & $\begin{array}{l}\text { Changing pattern and } \\
\text { frequency showed } \\
\text { abnormalities }\end{array}$ & $\begin{array}{l}\text { Almost different than } \\
\text { before stage of the } \\
\text { environmental condition }\end{array}$ \\
\hline $\begin{array}{l}\text { Core Views on long } \\
\text { term environmental } \\
\text { change }\end{array}$ & $\begin{array}{l}\text { Sound environmental } \\
\text { condition }\end{array}$ & $\begin{array}{l}\text { Observe not so much } \\
\text { changed than before }\end{array}$ & $\begin{array}{l}\text { Observational status } \\
\text { turned into pollution } \\
\text { activities }\end{array}$ & $\begin{array}{l}\text { Pollution status } \\
\text { appeared devastating } \\
\text { way }\end{array}$ & $\begin{array}{l}\text { Environmental } \\
\text { components consider to } \\
\text { be under threat }\end{array}$ \\
\hline $\begin{array}{l}\text { Core views on long } \\
\text { term social } \\
\text { insecurities }\end{array}$ & $\begin{array}{l}\text { More or less social } \\
\text { insecurities exist } \\
\text { except climatic }\end{array}$ & $\begin{array}{l}\text { Now at the recovery } \\
\text { trends but climatic } \\
\text { stress increase }\end{array}$ & $\begin{array}{l}\text { At the balancing stage } \\
\text { whereas social and } \\
\text { climatic stress parallel }\end{array}$ & $\begin{array}{l}\text { Social insecurity } \\
\text { increasing due to } \\
\text { global change }\end{array}$ & $\begin{array}{l}\text { Crop production fall, } \\
\text { livelihood change and } \\
\text { food insecurity }\end{array}$ \\
\hline More details & Compare to the & Growing economy & Agricultural activities & Technological & Agriculture related \\
\hline livelihood Pattern & $\begin{array}{l}\text { population growth, } \\
\text { almost stable }\end{array}$ & $\begin{array}{l}\text { owing to technological } \\
\text { development compare } \\
\text { to agriculture }\end{array}$ & $\begin{array}{l}\text { facing threat and } \\
\text { technologically evolving }\end{array}$ & $\begin{array}{l}\text { advancement but } \\
\text { agricultural sector } \\
\text { dwindled }\end{array}$ & $\begin{array}{l}\text { livelihood crisis but } \\
\text { technological almost } \\
\text { develop }\end{array}$ \\
\hline $\begin{array}{l}\text { More details on } \\
\text { productive trends }\end{array}$ & $\begin{array}{l}\text { Not so high } \\
\text { productivity }\end{array}$ & $\begin{array}{l}\text { Increased than previous } \\
\text { production rate }\end{array}$ & $\begin{array}{l}\text { Technological agricultural } \\
\text { activities and production } \\
\text { rate soar up }\end{array}$ & $\begin{array}{l}\text { Production rate and } \\
\text { genetically modified } \\
\text { species evolve but } \\
\text { climatic stress exist }\end{array}$ & $\begin{array}{l}\text { Severe climatic variability } \\
\text { exist and production rate } \\
\text { fallen due to instability of } \\
\text { the climatic controlling } \\
\text { parameter }\end{array}$ \\
\hline $\begin{array}{l}\text { Observational facts } \\
\text { on family crisis }\end{array}$ & $\begin{array}{l}\text { Not so severe except } \\
\text { one or two places }\end{array}$ & $\begin{array}{l}\text { Sometimes its appeared } \\
\text { as hazards due to } \\
\text { agricultural hazards }\end{array}$ & $\begin{array}{l}\text { A number of natural } \\
\text { hazards occur, so } \\
\text { critical to evaluate }\end{array}$ & $\begin{array}{l}\text { Natural hazards } \\
\text { occurring and } \\
\text { increase family crisis }\end{array}$ & $\begin{array}{l}\text { Now its common problem } \\
\text { due to climatic stress and } \\
\text { population growth }\end{array}$ \\
\hline $\begin{array}{l}\text { Thematic, realistic } \\
\text { and emotional } \\
\text { citation }\end{array}$ & $\begin{array}{l}\text { More generous and } \\
\text { transparent }\end{array}$ & $\begin{array}{l}\text { Involvement in } \\
\text { different sector and } \\
\text { realistic }\end{array}$ & $\begin{array}{l}\text { Number of sector } \\
\text { vulnerable due to } \\
\text { climate change }\end{array}$ & $\begin{array}{l}\text { Climate change } \\
\text { increase and make } \\
\text { vulnerable day by day }\end{array}$ & $\begin{array}{l}\text { Climatic vulnerability } \\
\text { increase and livelihood } \\
\text { shifting }\end{array}$ \\
\hline
\end{tabular}

\section{Existing Crisis and Future Trends}

Society and its component directly and indirectly are involved with the social welfare. It relies on situational and social factor but sometimes indicate to unexpected events it might be natural and anthropogenic induce. Natural cause of social uncertainty may evolve from any place and time depending on relevant factors with subjective cause. In contrast, anthropogenic activities is a key responsible parameter to initiate any unexpected incidents in a society. Relevant measurement calculate the loss of property comparing with the damage function and its frequency and magnitude. Nevertheless, environmental stress is one of the major problem for the social crisis in a society. Its latent hit and continuation can lead to accelerate the poverty and changing livelihood pattern. Social perception and their realization about environmental hazards (e.g., adaptation strategy) depends on their long term experience, education and social components (Table 2). Flood and drought hazards continue the changing pattern of socioeconomic condition in the developing world and make vulnerable to the local people while climate change will accelerate the present status in the near future (de Sherbinin et al., 2007; Hanson et al., 2011; McDonald et al., 2011). Now-a-days, owing to larger number of population growth and per capita income implies to demands for more food among the communities with augmenting incomes in particular Asia (Reardon et al., 2004). It is important to meet the demand through increasing production rate. On the other hand, it is very critical to meet the demands or secure for poor households through non-market and market channel due to resource limit or limit food security whereas available food at globally (Barrett, 2002). Regarding with FAO's information, total number of people increasing who are suffering from chronic hunger problem form 800 million (in 1996) to over a billion (FAO, 2009).

\section{Justification of the Lifesaving Strategy against with Environmental Hazards}

There are several life saving strategies against with those calamities. People of those hazard affected area basically look forward to save themselves from this. They patch up all of their essential things and go to the rahabitilizing centre for temporary settlement. They act as a group to slow down or minimize the effect of it. They also try to get some temporary work nearby, so that they can earn and not to roam only for relief. They mentally prepared for the betterment through not only looking towards government fund but also doing something efficient that can be helpful for their wellbeing. It should be taking some initiatives to discover some technique to recover any conditional barrier for the economic growth. It can be the best approach to control any situation case and its probable impacts.

\section{Mainstream Challenging Site}

The mainstream challenging site is the assessment of vulnerability and the adaptation of the society. To ensure fund for the programs, the awarness by the door 
to door campaign, the pre-disaster preparedness and the post-disaster settlement of the affected one's and the food security are the main challenging sites. These sites are very essential for the affected one's who are living along the coastal belts and other disaster prone area, thus the implementation can make a big difference for gearing up their livelihood.

\section{Mainstream Challenging Strategy on Hazards}

The hazards are naturally occuring. The loss of it only can be minimized by taking safety precautions and proper strategy. The proper effective radar network, Reliable and timely forecast capability for severe nor'wester, rapid and quick rescue system and local disaster action plans for the grassroot level can be the most challenging strategies on hazards. The precautions should be appropriate and the society should be aware of this which can build a crucial pathway for minimizing the loss.

\section{Evolving Technique for the Adaptation Approach}

The people of society takes part in many activities during those hazards for minimizing the not only lose but also for their adaptation. They try to find out part time jobs during disaster or involve them on various volounteery programs by many non-government and government organizations which offers "work for food". They also prefers to be accused with some sort of activities that could make them busy and to do something productive on that time.

The major challenges can helps to enable or accelerate the adaptation capacity without threating livelihood pattern against with environmental stress. Therefore, these activities requires different strategy whereas it may emerge from several area like as community based approach, farming and food system, enabling polices, improve institutional settings, diversification of production system, use of new technology and infrastructure improvement (Agrawal and Perrin, 2008).

\section{Situational Case on Time Measure}

In disaster prone area, peoples know the time schedule of the disasters. They estimated the time period of the disaster, they took necessary steps for adaptation on the basis of its aggressiveness using indigenous knowledge. They frame that time measure and handle the situation with involving them with many sort of activities in various voluntary programs. They handle those situation by involving the experiences which they got so far watching from their childhood and heard from the aged ones.

Government and non-government organizations can take many protective measure against these hazards such as introducing proper flood action plan, augmentation of surface water flow, construction of water reservoir, awareness building programs, reliable and timely warning and effective warning dissemination system, inventory of equipment for quick and rapid rescue system, proper radar network, proper implementation of building code for earthquake and many more. Not only that Local Disaster Action Plans for the grass root levels along the coastal belt should be enhanced but also it should be figure out the socioeconomic trends depending on specific crisis. Only some good initiatives along with the better implementation can minimize the loss of those disasters upon the affected ones.

Table 2. Total number of respondent's perception and their concept (e.g., response in percentage) against with specific number of on time environmental hazards measuring factors

\begin{tabular}{|c|c|c|c|c|}
\hline $\begin{array}{l}\text { On time measuring factors } \\
\text { against with environmental crisis }\end{array}$ & $>15$ years & $15-30$ years & $30-45$ years & $<45$ years \\
\hline $\begin{array}{l}\text { Lifesaving strategy against } \\
\text { with environmental hazard }\end{array}$ & $\begin{array}{l}\text { LS* } \\
\text { (14\% of the total } \\
\text { respondents) }\end{array}$ & $\begin{array}{l}\text { LS** } \\
\text { ( } 23 \% \text { of the total } \\
\text { respondents) }\end{array}$ & $\begin{array}{l}\text { LS*** } \\
\text { ( } 29 \% \text { of the total } \\
\text { respondents) }\end{array}$ & $\begin{array}{l}\text { LS**** } \\
\text { (34\% of the total } \\
\text { respondents) }\end{array}$ \\
\hline Mainstreaming Challenging Tactic & $\begin{array}{l}\text { MCT* } \\
\text { (16\% of the total } \\
\text { respondents) }\end{array}$ & $\begin{array}{l}\text { MCT** } \\
\text { (17\% of the total } \\
\text { respondents) }\end{array}$ & $\begin{array}{l}\text { MCT*** } \\
\text { (31\% of the total } \\
\text { respondents) }\end{array}$ & $\begin{array}{l}\text { MCT**** } \\
\text { (36\% of the total } \\
\text { respondents) }\end{array}$ \\
\hline $\begin{array}{l}\text { Mainstream challenging strategy } \\
\text { on hazard }\end{array}$ & $\begin{array}{l}\text { MCS* } \\
\text { ( } 09 \% \text { of the total } \\
\text { respondents) }\end{array}$ & $\begin{array}{l}\text { MCS** } \\
\text { (17\% of the total } \\
\text { respondents) }\end{array}$ & $\begin{array}{l}\text { MCS*** } \\
\text { (34\% of the total } \\
\text { respondents) }\end{array}$ & $\begin{array}{l}\text { MCS**** } \\
\text { ( } 40 \% \text { of the total } \\
\text { respondents) }\end{array}$ \\
\hline $\begin{array}{l}\text { Evolving technique for the } \\
\text { adaptation approach }\end{array}$ & $\begin{array}{l}\text { ETA* } \\
\text { (13\% of the total } \\
\text { respondents) }\end{array}$ & $\begin{array}{l}\text { ETA** } \\
\text { (19\% of the total } \\
\text { respondents) }\end{array}$ & $\begin{array}{l}\text { ETA*** } \\
\text { ( } 27 \% \text { of the total } \\
\text { respondents) }\end{array}$ & $\begin{array}{l}\text { ETA**** } \\
\text { ( } 41 \% \text { of the total } \\
\text { respondents) }\end{array}$ \\
\hline Situational case on time measure & $\begin{array}{l}\text { Incompetent } \\
\text { ( } 06 \% \text { of the total } \\
\text { respondents) }\end{array}$ & $\begin{array}{l}\text { Aware } \\
\text { ( } 15 \% \text { of the total } \\
\text { respondents) }\end{array}$ & $\begin{array}{l}\text { More competent } \\
\text { ( } 42 \% \text { of the total } \\
\text { respondents) }\end{array}$ & $\begin{array}{l}\text { Competent } \\
\text { ( } 37 \% \text { of the total } \\
\text { respondents) }\end{array}$ \\
\hline
\end{tabular}

Note: LS: Lifesaving Strategy against with Environmental Hazard; MCT: Mainstreaming Challenging Tactic; MCS: Mainstream Challenging Strategy on Hazard; ETA: Evolving Technique for the Adaptation Approach; '*' indicate to the significance level from lower to high $* * * *$ 


\section{Probable Outline and Mitigation Approach}

Social development indicate to socioeconomic growth and its probable controlling factor. As a driving factor its importance has been showed to the partial welfare for the communities. Sometimes, development trends inhabited by climatic curse. Climate change is one of the most important barrier for the social development. Social components and social development trends has been affected by negative consequences of natural and anthropogenic hazards (Rakib et al., 2015). Climatic variables instability leads to unwanted disaster like as flood and drought in the developing countries. In the consequences of that result, a number of people going to shelterless and suffering from food insecurities. In addition, agriculture based economy facing the risk in terms of livelihood crisis. In the developing country, most the people is suffered from climatic impacts owing to their extreme dependency on agro-economy, that's way rural people have largely impoverished and also responsible for agricultural subsistence and also they are not well equipped in technically and financially to change their conditions (Seaman et al., 2014). Most of the peoples are obliged to shift their livelihood pattern from existing position to another. But, to ensure sustainable development it needs to discover mitigation technique and probable outline to know how we can recovery our social crisis and make the continuation of development trends. The following equation could be guided to make clear concept on social crisis and probable mitigation approach to achieve sustainability in the community.

Social status deals with the socioeconomic growth that indicate to gross economic development in the society. However, one's per-capita income is one of the prime indicator in comparison with the total population. It is clear that, exclusively social development depends on socioeconomic growth. It might be the good indicator to evaluate the overall situation and its development stage of a society:

\section{Socioeconomic Growth \\ $=\frac{\text { One's per capita income } \times \text { Total income generating people }}{\text { Average expected life leading cost }( \pm \text { structural and }}$ nonstructural cost depending upon visual development status)}

People's life style is a mirror of socioeconomic growth but sometimes it might be influenced by some social and situational factor. However, it could be imped to the social development trends then it is important to consider climatic factors along with the rate of functional damage owing to unexpected loss for the evaluation of social development in the aspect of climate change. It could be a thematic outline for the vulnerable society to accelerate the development trends against with the loss of environmental hazards. A number of people is going to climatic refuge but it is more important to consider the situational case handling comparing with their socioeconomic growth and aim to ensure sustainable development at any cost:

Social Development $=$

well structured socioeconomic growth +

upward trends of structural and nonstructuralprogress

Social Disaster

Social development-overall loss for climatic hazards

How many times climatic hazards appear in a year? Or occurence

Poverty $=$

Socioeconomic growth - social disaster

Average costing to meet the basic needs

Sometimes, social crisis appeared as a social disaster in the developing country due to the long and short term consequences of the climatic hazards. It act as latent shocks for the future development trends in relation to magnitude and frequency of the respective climatic hazards. Depending on its results, socioeconomic growth might be follow downward trend for the yearlong to more. The negative consequences of the social development could be impacted on the per-capita income through mal functioning of the socioeconomic status. In the consequences, social and livelihood crisis appear in the local communities whereas it is not so easy to control the situation instantly. Food insecurity and/or poverty is the ultimate results of those social disasters. So, to ensure sustainable development it should be figure out a sustainable outline through considering the whole aspects of the climatic loss. It would be helpful to cope with the extensive loss through ensuring sustainable technique practices. Nevertheless, sustainable social development refers to the social development compile with the climatic damaging aspects but social disaster reducing technique would be guided to reduce the total climatic loss near to "zero":

$$
\begin{aligned}
& \text { Sustainable social development }=\text { Social development } \\
& -\left\{\begin{array}{c}
\text { apply social disaster reducing technique } \\
\text { which might be helps to eradicate poverty through } \\
\text { brings about the value of } \\
\text { social crisis almost zero }
\end{array}\right\}
\end{aligned}
$$

However, sustainable development can ensure to get sustainability in the livelihood trends. Sustainable livelihood pattern and its problematic site identification may lead to better understanding to social development through reducing social crisis. Recommended mitigation 
technique will be helpful to establish sustainability and food security against with the fighting climate change.

Social crisis and its probable effect reduction implies to existing social status along with the action of mitigation measures. Social and situational parameters attributed to the negative or positive approach to ensure sustainable development. In the community approach, it is critical to make balance in order to socioeconomic, educational status, skilled aware people, existing position and situation in the aspects of place, coexisting capacity in the aspects of vulnerability, livelihood insecurity in the aspects of percapita income and social insecure peoples (Fig. 1). It would be proficient way to disappear any social curse through evolving long term impacts if it is possible to get ensure on time measure of hazard and/or disaster. Whereas it could be approach through 'sustainable social clustering theory' as a key cite 'Social insecurity influence to one's life style which might be evolved in a society, possible to ensure sustainable development against with facing hazards through getting strengthen individual forwardness and situational factor".

It is very challenging and systematic to ensure sustainable food security therefore it is needed to plan wise action from decision-makers (Ericksen et al., 2009; Vermeulen et al., 2013). However, global food price, national policies and other may confine among land use types competition or able to build up adaptation capacity in the aspects of local actors like as poor urban communities and small-scale farmers (Mandemaker et al., 2011). Also, owing to shortage of resources and locallevel mechanism in terms of innovation and adaption may make possible to investments ineffective or largescale policies (Bourgeois et al., 2012).

Sometimes, a number of social crisis appeared as social hazards whereas it may influence to one's life style in the community. In some cases, problematic solution can drive away through charismatic analysis of the social factor. Factor depending social crisis may influence to communities welfare and socioeconomic growth. By the critical analysis of situation and social condition, probable findings may lead to better understanding of the existing crisis with proper guideline to control the situational hazards (Fig. 2). Regarding with the sustainable social clustering theory, it is very important to find out the realistic point of any crisis and its probable outline which would be directly emphasis on people's life style and guide to future policy making:

- The social rating system would be helpful for sorting out the whole population (e.g., clustering on vulnerability) regarding with social vulnerability

- It would be helpful to ensure intensive care according to social clustering of the vulnerable population

- $\quad$ Regarding with the findings, more vulnerable people shall be rescued and it should be required to recruit in different sectors at the time of hazard and/or disaster

- According to vulnerability, proper settlement of the social victim would be helpful to continue socioeconomic growth and to be effective to ensure sustainable development

- Environmental risk would be reduced and to be effective for the environmental hazard management from all sorts of the environmental components

The clustering mitigation approach of the social crisis would be helpful to reduce social hazards and to achieve sustainable development (Table 3). This approach could be lead to "zero" crisis by the ensuring step wise treatment of the community people for the development initiatives. If it is continued at the small and large scale, possible to ensure sustainable development against with adverse environmental condition:

$$
\begin{aligned}
& \text { Sustainable Social Development } \\
& =\text { Social development }-(\text { social crisis } ; x \rightarrow 0)
\end{aligned}
$$

Table 3. Noted five cluster along with its "rating and position" and probable feature at each of the rating and position to achieve sustainability

\begin{tabular}{|c|c|c|c|c|c|c|c|}
\hline & More vulnerable & More Illiterate & More Unskilled & More Risky & More Undefined & More Unhabituated & Remarks \\
\hline CL 1 & $\begin{array}{l}\text { Need to more } \\
\text { intensive care } \\
\text { to get stability }\end{array}$ & $\begin{array}{l}\text { Need to more } \\
\text { intensive care } \\
\text { to get stability }\end{array}$ & $\begin{array}{l}\text { Need to more } \\
\text { intensive care } \\
\text { to get stability }\end{array}$ & $\begin{array}{l}\text { Need to more } \\
\text { intensive care } \\
\text { to get stability }\end{array}$ & $\begin{array}{l}\text { Need to more } \\
\text { intensive care } \\
\text { to get stability }\end{array}$ & $\begin{array}{l}\text { Need to more } \\
\text { intensive care } \\
\text { to get stability }\end{array}$ & $\begin{array}{l}1^{\text {st }} \text { point to achieve } \\
\text { sustainability }\end{array}$ \\
\hline \multirow[t]{2}{*}{$C L 2$} & Vulnerable & Illiterate & Unskilled & Risky & Undefined & Unhabituated & \\
\hline & $\begin{array}{l}\text { Requisite to } \\
\text { intensive care } \\
\text { to get stability }\end{array}$ & $\begin{array}{l}\text { Requisite to } \\
\text { intensive care } \\
\text { to get stability }\end{array}$ & $\begin{array}{l}\text { Requisite to } \\
\text { intensive care } \\
\text { to get stability }\end{array}$ & $\begin{array}{l}\text { Requisite to } \\
\text { intensive care } \\
\text { to get stability }\end{array}$ & $\begin{array}{l}\text { Requisite to } \\
\text { intensive care } \\
\text { to get stability }\end{array}$ & $\begin{array}{l}\text { Requisite to } \\
\text { intensive care } \\
\text { to get stability }\end{array}$ & $\begin{array}{l}2^{\text {nd }} \text { point to achieve } \\
\text { sustainability }\end{array}$ \\
\hline \multirow[t]{3}{*}{ CL 3} & More or less & More or & More or & More or & More or & More or & \\
\hline & secure & less literate & less skilled & less safe & less defined & less habituated & \\
\hline & $\begin{array}{l}\text { More or } \\
\text { less stable }\end{array}$ & $\begin{array}{l}\text { More or less } \\
\text { stable }\end{array}$ & $\begin{array}{l}\text { More or } \\
\text { less stable }\end{array}$ & $\begin{array}{l}\text { More or } \\
\text { less stable }\end{array}$ & $\begin{array}{l}\text { More or } \\
\text { less stable }\end{array}$ & $\begin{array}{l}\text { More or } \\
\text { less stable }\end{array}$ & $\begin{array}{l}3^{\text {rd }} \text { point to achieve } \\
\text { sustainability }\end{array}$ \\
\hline CL 4 & $\begin{array}{l}\text { Secure } \\
\text { Stable }\end{array}$ & $\begin{array}{l}\text { Educated } \\
\text { Stable }\end{array}$ & $\begin{array}{l}\text { Skilled } \\
\text { stable }\end{array}$ & $\begin{array}{l}\text { Safe } \\
\text { Stable }\end{array}$ & $\begin{array}{l}\text { Defined } \\
\text { stable }\end{array}$ & $\begin{array}{l}\text { Habituated } \\
\text { stable }\end{array}$ & $\begin{array}{l}4^{\text {th }} \text { point to achieve } \\
\text { sustainability }\end{array}$ \\
\hline CL 5 & $\begin{array}{l}\text { More secure } \\
\text { More stable }\end{array}$ & $\begin{array}{l}\text { Higher Educated } \\
\text { More stable }\end{array}$ & $\begin{array}{l}\text { More Skilled } \\
\text { More stable }\end{array}$ & $\begin{array}{l}\text { More safe } \\
\text { More stable }\end{array}$ & $\begin{array}{l}\text { Well defined } \\
\text { More stable }\end{array}$ & $\begin{array}{l}\text { More habituated } \\
\text { More stable }\end{array}$ & $\begin{array}{l}5^{\text {th }} \text { point to achieve } \\
\text { sustainability }\end{array}$ \\
\hline
\end{tabular}
regarding with prescribe cluster 


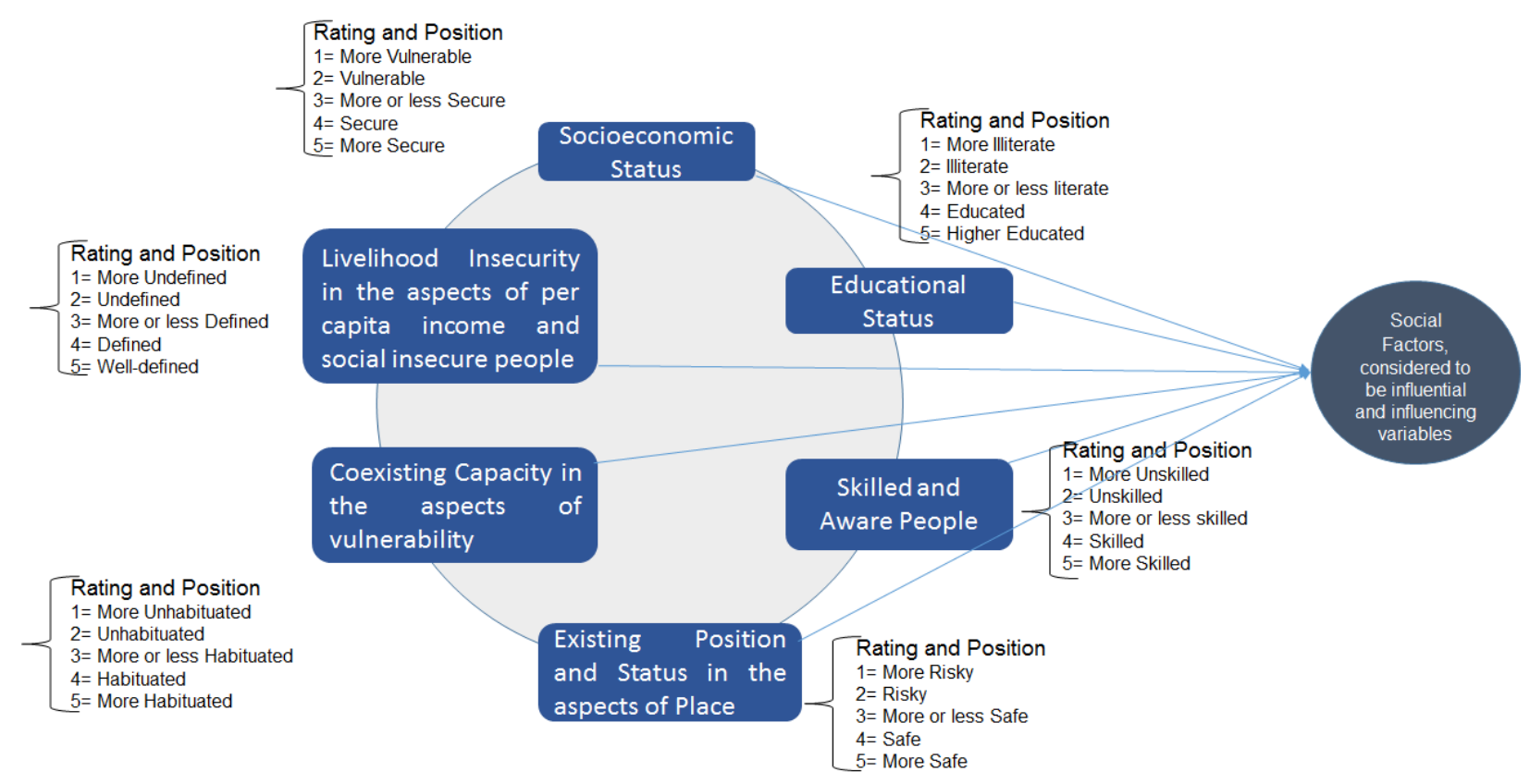

Fig. 1. Social factor and its rating power sequence (e.g., its rating power sequences would be helpful to identify the social people in different ways of problem and guide to suggestive policy approach to recover social crisis to ensure sustainable development)

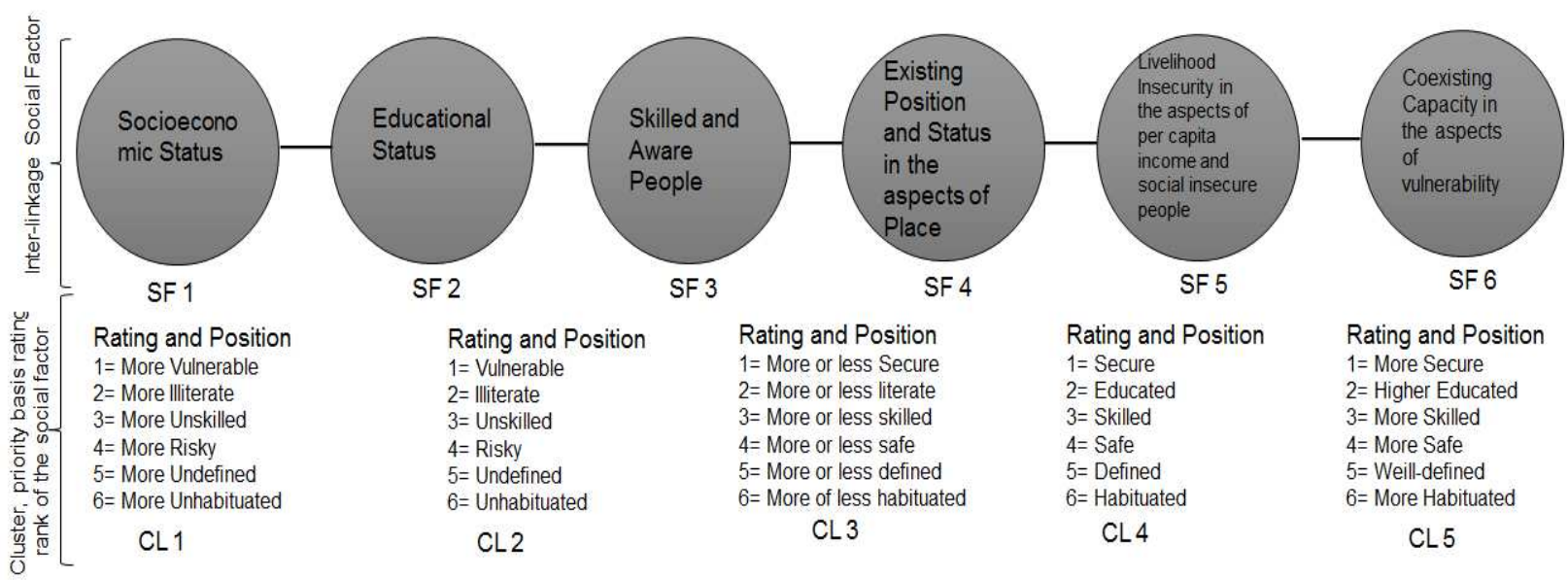

Fig. 2. Showing social insecurity and its probable outline. This guideline indicate to sustainable society, more consistence among the social variables whereas sustainable social clustering technique is a milestone to rescue insecure people from the community. It would be led to a new way of minimize food shortage problem from the local community owing to curse of climatic hazards

However, social crisis is one of the most prevalent curse in the developing country. Sometimes, it is not easy to control in the aspects of situational case like as frequency and magnitude of any natural or anthropogenic hazards. In Bangladesh, drought and flooding hazards directly implies to negative consequences due to the long term variation of climatic variables. Consecutively, a number of peoples who are living below the poverty line, to be consider the main victim in the sequential manner of poor socioeconomic condition. Simultaneously, other factors follow to one and another path to hit in different way. In the way to similar action, it may appear as a devastating way to dismiss of a arrange family and to make them out bursting, helpless, shelterless and foodless. Nevertheless, it would be possible to settle down of any curse form a society if it is followed by the way of action through suggestive policy execution. 


\section{Conclusion}

Natural threat is a major concern in the developing country. Its negative consequences affect to the whole aspects of the social component. In Bangladesh, flooding hazards are common issue that's are responsible to make feeble structure of the communities through creating fundamental crisis. It was tried to find out the real scenario whereas a number of people suffered from food shortage problem due to climatic hazards. In the long term aspects, it might be appeared as a devastating barrier in the way of social development. At the time of hazard, local people try to cope with adverse environmental condition through building up indigenous technology and strategy. Regarding with respondents pragmatic experience, rush changing pattern of climatic variables has been showed some anomalies in flooding hazards occurring time, interval, frequency, magnitude and its probable damage function. However, it is important to figure out the real problem and find out the probable solution to ensure sustainable development. Depending on problematic area, it was tried to build up 'social clustering theory' which would be helpful to find out the social victim and proper action to suggestive policy to ensure sustainability against with social crisis.

\section{Acknowledgement}

The author acknowledged to the local respondents who has been made me easiest to perform an outstanding research through shearing of their experience.

\section{Authors Contributions}

M.A. Rakib: Contributed in developing concept, designed the study, wrote the protocol and wrote the first the first draft of the manuscript and also prepared the final version of the manuscript. Finally, read and approved the final manuscript.

M.S. Akter: Contributed in managing the literature searches and took part in the analysis into the concept required. Finally, read and approved the final manuscript.

Kushal Majumder: Contributed in managing the literature searches, read and approved the final manuscript.

\section{Compete of Interest}

Author declared that, has no compete of interest.

\section{References}

Adger, W.N., 1999. Social vulnerability to climate change and extremes in coastal Vietnam. World Dev., 27: 249-269.

DOI: $10.1016 / \mathrm{S} 0305-750 \mathrm{X}(98) 00136-3$
Agrawal, A. and N. Perrin, 2008. Climate adaptation, local institutions and rural livelihoods. International Forestry Resources and Institutions Program (IFRI) Working Paper \# W08I-6. University of Michigan.

Barrett, C.B., 2002. Food Security and Food Assistance Programs. In: Handbook of Agricultural Economics, Gardner, B.L. and G.C. Rausser (Eds.), Elsevier Science, Amsterdam.

Bourgeois, R., J., Ekboir, C. Sette, C. Egal and M. Wongtchowsky et al., 2012. The State of Foresight in Food and Agriculture and the Roads Toward Improvement. 1st Edn., GFAR, Rome.

Chambers, R., 1994. The origins and practice of participatory rural appraisal. World Dev., 22: 953- 69. DOI: 10.1016/0305-750X(94)90141-4

Corbin, J. and A. Strauss, 1990. Grounded theory research: Procedures, cannons and evaluative criteria. Qualitative Sociol., 13: 3-21.

DOI: 10.1007/BF00988593

de Sherbinin, A., A. Schiller and A. Pulsipher, 2007. The vulnerability of global cities to climate hazards. Environ. Urban, 19: 39-64. DOI: $10.1177 / 0956247807076725$

Ericksen, P.J., J.S.I. Ingram and D.M. Liverman, 2009. Food security and global environmental change: Emerging challenges. Environ. Sci. Policy, 12: 373- 377. DOI: $10.1016 /$ j.envsci.2009.04.007

FAO, 2009. The state of food security in the world. Food and Agriculture Organization of the United Nations, Rome.

Gain, A.K., W.W. Immerzeel, F.C. Sperna-Weiland and M.F.P. Bierkens. 2011. Impact of climate change on the stream flow of the lower Brahmaputra: Trends in high and low flows based on discharge-weighted ensemble modelling. Hydrol. Earth Syst. Sci. Dis., 8: 365-390. DOI: 10.5194/hess-15-1537-2011

Gershberg, A.L., 1998. Decentralization, recentralization and performance accountability: Building an operationally useful framework for analysis. Dev. Policy Rev., 16: 405-31. DOI: $10.1111 / 1467-7679.00071$

Gibson, N., 2004. Action Research. In: The Sage Encyclopedia of Social Science Research Methods, Lewis-Beck, M.S., A. Bryman and T.F. Liao (Eds.), Sage, Thousand Oaks, pp: 4-6.

Habiba, U., R. Shaw and Y. Takeuchi, 2012. Farmer's perception and adaptation practices to cope with drought: Perspectives from Northwestern Bangladesh. Int. J. Disaster Risk Reduct., 1: 72-84. DOI: 10.1016/j.ijdrr.2012.05.004

Habiba, U., R. Shaw and Y. Takeuchi. 2011. SocioEconomic Impact of Droughts in Bangladesh. In: Droughts in Asian Monsoon Region: Community, Environment and Disaster Risk Management, Shaw, R. and N. Huy (Eds.), Emerald Publication, pp: 25-48. 
Hanson, S., R. Nicholls, N. Ranger, S. Hallegatte and J. Corfee-Morlot et al., 2011. A global ranking of port cities with high exposure to climate extremes. Clim. Change, 104: 89-111. DOI: $10.1007 / \mathrm{s} 10584-010-9977-4$

Immerzeel, W., 2008. Historical trends and future predictions of climate variability in the Brahmaputra basin. Int. J. Climatol., 28: 243-254. DOI: $10.1002 /$ joc. 1528

IPCC, 2014. Livelihoods and Poverty, Climate Change: Impacts, Adaptation and Vulnerability. Volume 1: Global and Sectoral Aspects. Final Draft.

Luers, A.L., D.B. Lobell, L.S. Sklar, C.L. Addams and P.A. Matson, 2003. A method for quantifying vulnerability, applied to the agricultural system of the Yaqui Valley, Mexico. Global Environ. Change, 13: 255-267.

DOI: 10.1016/S0959- 3780(03)00054-2

Mandemaker, M., M. Bakker and J. Stoorvogel, 2011. The role of governance in agricultural expansion and intensification: A global study of arable agriculture. Ecol. Soc., 16: 8-8.

DOI: $10.5751 /$ ES- 04142-160208

McDonald, R.I., I. Douglas, C. Revenga, R. Hale and N. Grimm et al., 2011. Global urban growth and the geography of water availability, quality and delivery. AMBIO, 40: 437-446.

DOI: $10.1007 / \mathrm{s} 13280-011-0152-6$

Patwary, M.A., W.T. O’Hare and M.H. Sarker, 2012. Occupational accident: An example of fatalistic beliefs among medical waste workers in Bangladesh. Safety Sci., 50: 76-82. DOI: 10.1016/j.ssci.2011.07.004

Paul, B.K., 1997. Flood research in Bangladesh in retrospect and prospect: A review. Geoforum, 28: 121-131. DOI: 10.1016/S0016-7185(97)00004-3

Paul, B.K., 1998. Coping mechanisms practised by drought victims (1994/5) in North Bengal, Bangladesh. Applied Geography, 18: 355-73.

Rakib, M.A., M.A. Rahman, M.S. Akter and M.A.H. Bhuiyan, 2014. Climate change: Farmer's perception and agricultural activities. Herald J. Geography Regional Plann., 3: 115-123.
Rakib, M.A., M.S. Akter, M.B. Hossain, M.A. Rahman and M.A.H. Bhuiyan. 2015. Flooding hazards and mental perception: A theoretical framework. J. Scientific Res. Rep., 5: 140-151. DOI: $10.9734 / J S R R / 2015 / 13706$

Reardon, T., P. Timmer and J. Berdegue, 2004. The rapid rise of supermarkets in developing countries: Induced organizational, institutional and technological change in agrifood systems. J. Agric. Dev. Econom., 1: 168-183.

Seaman, J.A., G.E. Sawdon, J. Acidri and C. Petty, 2014. The household economy approach. Managing the impact of climate change on poverty and food security in developing Countries. Climate Risk Manage., 4-5: 59-68.

DOI: $10.1016 /$ j.crm.2014.10.001

Smith, K. and D.N. Petley, 2009. Environmental Hazards: Assessing Risks and Reducing Disasters. 1st Edn., Routledge, London.

Tompkins, E.L. and W.N. Adger, 2004. Does adaptive management of natural resources enhance resilience to climate change? Ecol. Society, 9: 10-10.

Tong, T., R. Shaw and Y. Takeuchi, 2012. Climate disaster resilience of the education sector in Thua Thien Hue province, Central Vietnam. Natural Hazards, 63: 685-709.

DOI: $10.1007 / \mathrm{s} 11069-012-0178-5$

Turner, B.L.I., R.E. Kasperson, P.A. Matson, J.J. McCarthy and R.W. Corell et al., 2003. A framework for vulnerability analysis in sustainability science. Proc. Nat. Acad. Sci. USA., 100: 8074-8079. DOI: 10.1073/pnas. 1231335100

Vermeulen, S.J., A.J. Challinor, P.K. Thornton, B.M. Campbell and N. Eriyagama et al., 2013. Addressing uncertainty in adaptation planning for agriculture. Proc. Nat. Acad. Sci. USA., 110: 8357- 8362. DOI: 10.1073/pnas. 1219441110

West, C.T., C. Roncoli and F. Ouattara, 2007. Local perceptions and regional climate trends on the Central Plateau of Burkina Faso. Land Degradat. Dev., 19: 289-304. DOI: 10.1002/ldr.842

Wheeler, T. and J. Von Braun, 2013. Climate change impacts on global food security. Science, 341: 508-513. DOI: $10.1126 /$ science. 1239402 